\title{
Minimum geotechnical requirements for traditional and singular bridges foundations design: Chacao Suspension Bridge
}

\author{
Requerimientos geotécnicos mínimos para el diseño de fundaciones de puentes tradicionales y \\ singulares: Puente Colgante Chacao
}

\section{Álvaro Peña (Mail Author)}

Pontificia Universidad Católica de Valparaíso, Facultad de Ingeniería

Escuela de Ingeniería en Construcción

Avda. Brasil 2147, Valparaíso (Chile)

alvaro.pena@pucv.cl

\section{Matías Valenzuela}

Pontificia Universidad Católica de Valparaíso, Facultad de Ingeniería Escuela de Ingeniería en Construcción

Avda. Brasil 2147, Valparaíso (Chile)

matias.valenzuela@pucv.cl

\section{Marcelo Márquez}

Ministerio de Obras Públicas, Dirección de Vialidad

Morandé 59, Santiago (Chile)

marcelo.marquez@mop.gov.cl

\section{Hernán Pinto (Corresponding Author)}

Pontificia Universidad Católica de Valparaíso, Facultad de Ingeniería Escuela de Ingeniería en Construcción

Avda. Brasil 2147, Valparaíso (Chile)

hernan.pinto@pucv.cl

Manuscript Code: 863

Date of Acceptance/Reception: 23.11.2017/07.12.2016

DOI: 10.7764/RDLC.16.3.498

\begin{abstract}
Bridges projects, usually considered a wide range of geotechnical research for the design of foundations. These works are of considerable importance for the proper design of foundations (shallow or deep) as well as to avoid problems during the project execution (time, cost, safety, complementary campaigns, etc.). This paper aims to analyze criteria and minimum geotechnical requirements for the project development of traditional and long-span bridges in Chile, taking into account international and national experience, considering as case of study the Project of Design and Construction of Chacao Bridge: multi-span suspension bridge with two main spans, 1,055 m and 1,155 m, currently underway in southern Chile, as a result of this work a summary of the minimum geotechnical requirements needed is proposed.
\end{abstract}

Key words: Geotechnical bridges studies, Chacao Bridge, bridge foundations.

Resumen

Para el desarrollo de proyectos de puentes, de grandes luces, por lo general se considera una gran variedad de investigaciones geotécnicas a la hora de diseñar las fundaciones. Estos trabajos son de gran importancia a la hora de diseñar de forma adecuada las fundaciones de los puentes, ya sean profundas o superficiales, además de que la correcta realización de estos estudios evitarán una serie de problemas durante la fase de ejecución del proyecto (tiempo, costos, seguridad, estudios complementarios, etc.). Este artículo, se centra en analizar los criterios y requerimientos geotécnicos mínimos para desarrollar proyectos de puentes tradicionales y de grandes luces en Chile, para lo cual se ha tomado en cuenta la experiencia internacional y nacional. En el artículo se considera el caso de estudio correspondiente al Proyecto de Diseño y Construcción del Puente de Chacao, un puente de colgante con dos tramos principales, de 1055 m y 1155 m en ejecución en el Sur de Chile, entregando como resultado de este trabajo una propuesta de requerimientos geotécnicos mínimos

Palabras clave: Requerimientos geotécnicos, puentes, puente colgante, Puente Chacao.

Long span bridges, as well traditional bridges, are usually a major infrastructure project that generally involved a large budget, from previous studies, design, detailed engineering, construction, and operation. Never the less every project is singular and unique, from the engineering point of view there are some minimum requirements needed for the 
structural design and engineering. Until now, these projects are mainly based on the experience of engineers, and in the particular case of the case of study in this paper, for the experience of the engineers of the Public Infrastructure Minister of Chile, starting from this situation, in this paper a research work is conducted in order to determine the minimal geotechnical requirements needed in order to obtain a safety design of the infrastructure and also to avoid delays in the engineering and construction phase of the project due to incomplete data from previous studies. In section 2 of the paper, a detailed description of the problem is presented, then in the state of the art section a detailed analysis of traditional bridges geotechnical requirements is conducted for then analyze the Chacao Bridge case providing the needed information, then, the results are summarized in a table with the parameters needed, finally the conclusions of the work are presented.

\section{Description of the Problem}

For bridges foundations definitions, especially when they are of great span or of special conditions, due to land singularity or aspects imposed by the structure itself, a high degree of geotechnical knowledge and certainty must be reached in order to allow the designers undertake the foundations design confidently, assuring proper collapse, overturning as well as sliding safety factors and guaranteed land-foundation stability for most unfavorable feasible conditions, according to applicable technical standards. To meet these requirements, is essential to count with reliable geotechnical data, often at odds with tight deadlines, pressed by project development schedule. Therefore, complementary campaigns during construction phase are also important, because these campaigns allow to clarify issues and in some cases complete ground features not duly researched in the initial studies.

In the case of singular projects, the exposed problematic turns more complex because of ground variability, boundary conditions (streambed or seabed) and principally due to the lack of regional and national standards in this matter.

In this context, this paper aims to analyze criteria and geotechnical requirements for the project development of traditional and long-span bridges in Chile, taking into account international and national experience, considering as case of study the Project of Design and Construction of Chacao Bridge (Figure 1).

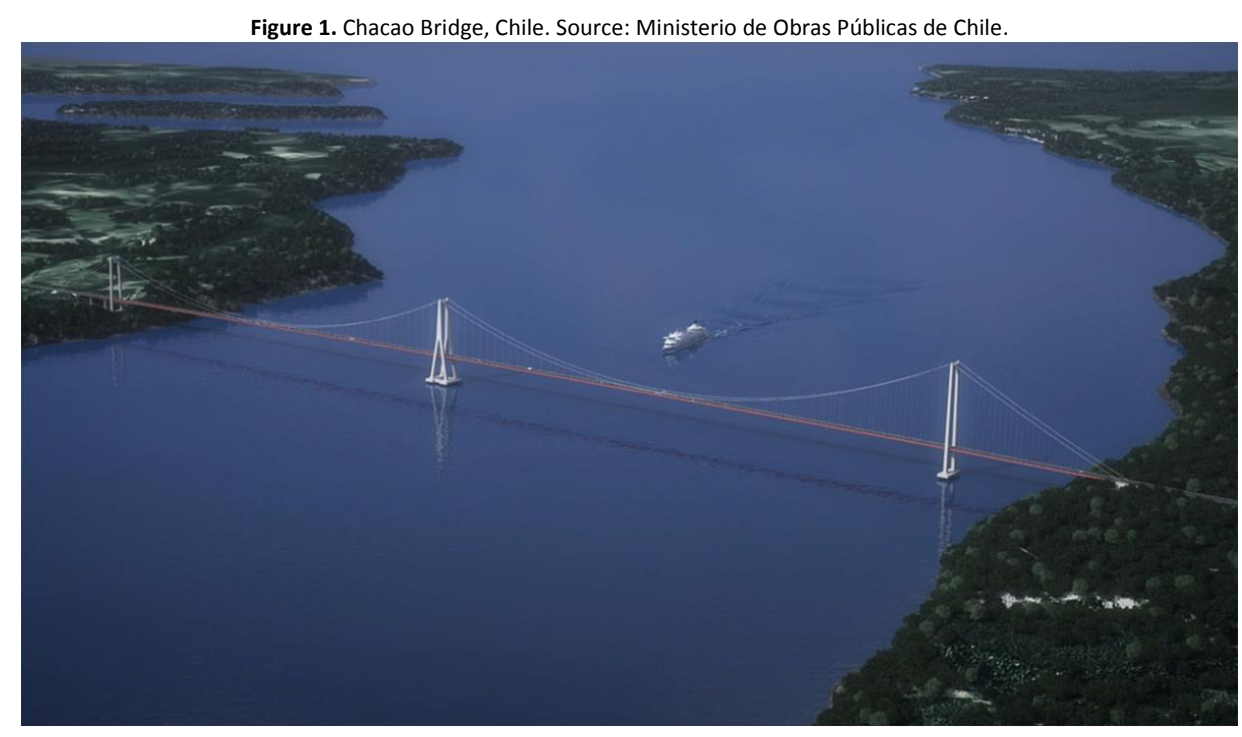

State of the Art: Traditional Bridges Geotechnical Requirements

The majority of planned and built bridges across Chile corresponds to an isostatic typology, with a beam system with reinforced concrete deck slabs. These beams are mainly of reinforced concrete, prestressed or post-tensioned, reaching spans of about $50 \mathrm{~m}$. Besides, since the 90 's continuous bridges with isolation systems supported on abutments and piers over pile foundations has been implemented (Valenzuela, Marquez, \& Vallejo, 2015).

According to international and national standards review, geotechnical studies for bridges, especially for its foundations design, must consider site geometry (at least bi-dimensional, but as preference tri-dimensional) as well as the stratums of seismic waves propagation and the land-foundation interaction, together with the study of non-linear and non-elastic soil behavior (AASHTO, 2012; Eurocode, n.d.; Fomento., 2009; MOP, 2014). 
In the other hand, an aspect of increasing importance, especially regarding bridges with deep foundations, is the study of the interaction between piles in order to assess the potential effects of loading and unloading cycle's accumulation over the soil behavior, and individual piles study as well as group effect.

In the case of bridges with deep foundations over soft soils, zones with groundwater table variation or presence of big overloads on the terrain, the study of parasite effects (horizontal forces increase and negative friction) requires special studies, where the characterization of the foundation soil should be focused in this difficulty (Peña, MarquezMarambio, \& LLorens-Alcón, 2013)

In zones with seismic risk, specific onsite and laboratory test shall be performed, aiming to obtain the dynamic properties of the soils, such as: degradation under cyclic loads (resistance, volume or pore pressure changes), volumetric density, damping, stiffness, resistance and shear waves speed.

The following table contains the minimum soil mechanics tests required according to Manual de Carreteras of the Roadways Department of Ministry of Public Works and practical experience in traditional Chilean bridges (Arriagada \& Contreras, 2015).

\begin{tabular}{|c|c|c|}
\hline Surveys & - & Drillings \\
\hline & - & Test pits \\
\hline \multirow[t]{2}{*}{ Onsite testing } & Soil & Permeability \\
\hline & Soil & SPT \\
\hline \multirow[t]{15}{*}{ Laboratory testing } & Soil & Particle Size Distribution \\
\hline & Soil & Plasticity Index \\
\hline & Soil & Bulk Weight \\
\hline & Soil & Natural Density \\
\hline & Soil & Moisture Content \\
\hline & Soil & Proctor or Relative \\
\hline & & Density \\
\hline & Soil & Triaxial \\
\hline & Soil & Permeability \\
\hline & Soil & Liquefaction Potential \\
\hline & Soil & Specific Gravity \\
\hline & Rock & Uniaxial Compression \\
\hline & Rock & Direct Shear \\
\hline & Chemical & Sulphides Content \\
\hline & Chemical & Chlorides Content \\
\hline
\end{tabular}

\section{Methodology: Chacao Bridge Geotechnical Requirements}

Chacao Bridge Project considers a multi-span suspension bridge with three reinforced concrete piles, two anchoring blocks, two abutments and one approaching viaduct of three spans over piers. Its main foundations, located in the seabed (Chacao Channel), corresponds to a system of pre-excavated piles with waling, while the foundation of the southern pile - located in Chiloé Island - directly over the terrain. Likewise, the viaduct's anchoring blocks, abutments as well as piers foundations go directly over the terrain (Valenzuela \& Marquez, 2014).

Taking as case of study the Project of Design and Construction of Chacao Bridge, the present geotechnical requirements aims to obtain the minimum geotechnical background needed for the final project and the bridge foundation systems construction (MOP, 2013), which complement the geotechnical campaigns performed between years 2001 and 2006.

For the three main piles foundations design development, the following onsite works and tests are considered. 


\section{Onsite geotechnical works and tests}

\section{Drillings}

For the northern pile are considered five drillings ( 3 Geobor S, 2 SPT and 1 pressure measuring survey). The depth of the drillings should be at least the one where the increase of the vertical load reaches $10 \%$ of the net contact pressure, without stratums that may suffer unacceptable settlements while being under such load increase. Also, the drillings consider a recognition depth of $100 \mathrm{~m}$, using for it drilling, sampling and soil testing equipment.

For the central pile located over Swirl Rock (almost at the surface geological promontory) are considered three drillings (1 SPT, 1 Geobor S plus geophysical survey and 1 pressure gauge).

Additionally, there are considered drillings for the southern pile (4), for the southern anchoring block (4), for the northern anchoring block (5), for the approaching viaduct (3, one per pier) y for the northern abutment (2).

The drillings must be located in opposite ends of one of the foundation diagonals and in its center.

For the rock drilling is considered a triple tube core barrel, with diameter equal or greater than the one corresponding to HQ3 system.

Regarding the Standard Penetration Test SPT (ASTM D-1586-11), as minimum, must be executed in all drillings each $1 \mathrm{~m}$ or until refusal.

For the drillings of the northern and central pile, a Jack Up platform is utilized as supporting element.

\section{Pressure measuring surveys}

Pressure measuring surveys are performed with Menard equipment able to reach final exploration depths and maximum pressure of $10 \mathrm{MPa}$ (for hard soils and soft rocks).

The pressure measuring surveys are executed in at least 1 drilling per element, which are drilled in compatible diameters regarding the diameter of the pressure probe.

The surveys are executed in intervals of $2.5 \mathrm{~m}$ until reach $50 \mathrm{~m}$ depth and each $5 \mathrm{~m}$ between the $50 \mathrm{~m}$ and the final drill depth.

\section{Permeability tests}

The execution of Lefranc or modified Lugeon permeability tests is considered, according to the soil types. The equipment allows the tests execution with double packer and until the final drillings depths.

Tests are performed in intervals of $10 \mathrm{~m}$.

\section{Geophysics}

The following geophysical tests are performed in each new foundation location (piles or anchoring blocks),

- Shear waves speed measurement until $100 \mathrm{~m}$ depth

- Rock resistivity measurement

In all drillings $\mathrm{P}$ and S (Compression and Share) speed profiles are determined. Measurements are executed each $1 \mathrm{~m}$ depth.

In order to measure speed within the drilling, as well as density measurement and soil porosity, the equipment Logger Suspension OYO is utilized.

For this purposes, Gamma-Gamma and Neutron-Neutron probes are utilized. 
Must be performed geophysical surveys able to locate seabed level, quaternary deposits depth, underlying rock heads and active faults in such rocks.

\section{Soil Dynamics}

Soil geodynamics properties are determined, such as: degradation under cyclic loads (resistance, volume or pore pressure changes), volumetric density, damping, stiffness and resistance.

Shear modulus of small unitary deformations is directly determined through the shear waves speed measurements, while degraded shear modulus regarding unitary shear cyclic deformations, is determined through resonant column and triaxial tests. The variation of the damping with the shear unitary deformation is also determined with these tests.

For the bridge foundations seismic analysis, especially regarding waves propagation, it is considered the soil threedimensional nature, including geodynamic information regarding wave's propagation speed in the different identified strata, to be utilized in the foundation dynamic modelling.

\section{Laboratory Tests}

For Chacao Bridge Project, laboratory tests are performed according to corresponding ASTM standards. Performed tests are detailed in table below.

\begin{tabular}{|c|c|c|}
\hline Material & Test & ASTM \\
\hline \multirow[t]{21}{*}{ Soil } & 1) Classification & \\
\hline & - Particle-Size Analysis (sieving and sedimentation) & LNV 105 \\
\hline & - Atterberg Limits & NCh $1517 / 1$ y \\
\hline & - USCS Classification & II \\
\hline & - Specific Weight (Wet Density) & D2487 \\
\hline & - Moisture Content & NCh 1532 \\
\hline & 2) Specific Gravity & NCh 151 \\
\hline & 3) Uniaxial Compression & D584 \\
\hline & 4) Triaxial Compression CIU & D2166 \\
\hline & 5) Direct Shear (soils) & D4767/D2850 \\
\hline & 6) Oedometer test (consolidation) & D3080 \\
\hline & 7) Geochemical tests & D2435 \\
\hline & - Alkalinity $(\mathrm{pH})$ & \\
\hline & - Sulphides Content & D4972 \\
\hline & - Chlorides Content & C1580 \\
\hline & - Organic Matter Content & D1411 \\
\hline & - Carbonate Content & D2974 \\
\hline & 8) Cyclic triaxial test for seismic parameters & D4373 \\
\hline & 9) Cyclic triaxial test to determine long term fatigue & D5113 \\
\hline & 10) Resonant column test in soils & D5113 \\
\hline & & D4015 \\
\hline \multirow[t]{7}{*}{ Rock } & 1) Uniaxial compression in rocks (with Young's & D7012 \\
\hline & Modulus measurement) & \\
\hline & 2) Wet density, specific gravity, porosity & D7263 \\
\hline & 3) Punctual load in rocks & D5731 \\
\hline & 4) Brazilian test & $\mathrm{N} / \mathrm{A}$ \\
\hline & 5) Triaxial compression CIU & D4767 \\
\hline & 6) Mineralogical analysis & C1721 \\
\hline \multirow[t]{3}{*}{ Water } & 1) Alkalinity $(\mathrm{pH})$ & D4972 \\
\hline & 2) Sulphides Content & C1580 \\
\hline & 3) Chlorides Content & D1411 \\
\hline
\end{tabular}


In particular, the study of the structure's site axis contains as minimum the following information:

- Detailed terrain stratigraphy for each foundation site of the bridge. This includes under qualified soil strata or layers locations, faults and altered rock layers

- Shear waves propagation speed in the different stratum.

- Index properties of each layer (Moisture content, Atterberg limits, Unit weight, Specific weight of solid particles, particles angularity and grain size analysis, chemical attack resistance ( $\mathrm{pH}$, Sulphides, Chlorides), mineral type.

- Strength and stiffness parameters of all stratum in the bridge foundations influence zone:

- Soil cohesion and internal friction angle.

- Deformation Modulus for the range of soils confining stress.

- Stress-strain relationship in active and passive condition for the range of soils confining stress.

- Poisson's ratio.

- Deformations due to slow creep and the action of cycle loads, including permanent deformations

- Cyclical behavior of soils where foundations are located, for stress levels according to bridge design.

\section{Results}

According to the performed review of international and national standards, such as Manual de Carreteras (MOP, 2013, 2014) Euro code (Eurocode, n.d.) Foundations Guide (Fomento., 2009) and AASHTO (AASHTO, 2012), and the case of study Chacao Bridge Project. In Table 3 and Table 4 the different types of geotechnical studies that can be done for traditional and singular bridges are presented, taking into account surveys, onsite tests and laboratory tests.

Table 3. Proposal of traditional and singular bridges geotechnical studies. Source: Prepared by the authors.

\begin{tabular}{|c|c|c|c|c|}
\hline \multirow{2}{*}{\multicolumn{3}{|c|}{ Geotechnical Studies }} & \multicolumn{2}{|c|}{ Bridges } \\
\hline & & & \multirow{2}{*}{$\frac{\text { Traditional }}{\sqrt{ }}$} & \multirow{2}{*}{$\frac{\text { Singular }}{\sqrt{ }}$} \\
\hline Researches & $\begin{array}{ll}---- \\
\end{array}$ & Borehole & & \\
\hline & & Test pit & $\checkmark$ & $\checkmark$ \\
\hline & & Geophysics & $\sqrt{ } *$ & $\checkmark$ \\
\hline \multirow[t]{15}{*}{ In-situ tests } & Soil & Load plate & $x$ & $x$ \\
\hline & & Permeability & $\checkmark$ & $\checkmark$ \\
\hline & & SPT & $\checkmark$ & $\checkmark$ \\
\hline & & Pressuremeter & $x$ & $\checkmark$ \\
\hline & & Static penetrometer & $\sqrt{ }^{*}$ & $\sqrt{ }$ \\
\hline & & CPT & $x$ & $\sqrt{ }^{*}$ \\
\hline & & Dynamic cone & $x$ & $\checkmark$ \\
\hline & & CPTU & $x$ & $\checkmark$ \\
\hline & & Whirligig & $x$ & $\checkmark$ \\
\hline & & Vs and Vp & $x$ & $\checkmark$ \\
\hline & & Done hole & $x$ & $\checkmark$ \\
\hline & & SEV & $x$ & $\checkmark$ \\
\hline & & Cross hole & $x$ & $\checkmark$ \\
\hline & Rock & Dilatometer & $x$ & $\checkmark$ \\
\hline & & Shear Palette & $x$ & $\sqrt{ }$ \\
\hline \multirow[t]{9}{*}{ Laboratory tests } & Chemicals & Organic content & $x$ & $\checkmark$ \\
\hline & & Electrochemical classification & $x$ & $\checkmark$ \\
\hline & & Gypsum content & $x$ & $\checkmark$ \\
\hline & & $\begin{array}{l}\text { Resistance to chemical agents, } \\
\text { sodium sulphate and magnesium }\end{array}$ & $x$ & $\checkmark$ \\
\hline & & Carbonate content & $x$ & $\checkmark$ \\
\hline & & Sulphate content & $\checkmark$ & $\checkmark$ \\
\hline & & Content of soluble salt content & $x$ & $\checkmark$ \\
\hline & & Chlorides content & $\checkmark$ & $\checkmark$ \\
\hline & & pH content & $x$ & $\checkmark$ \\
\hline
\end{tabular}




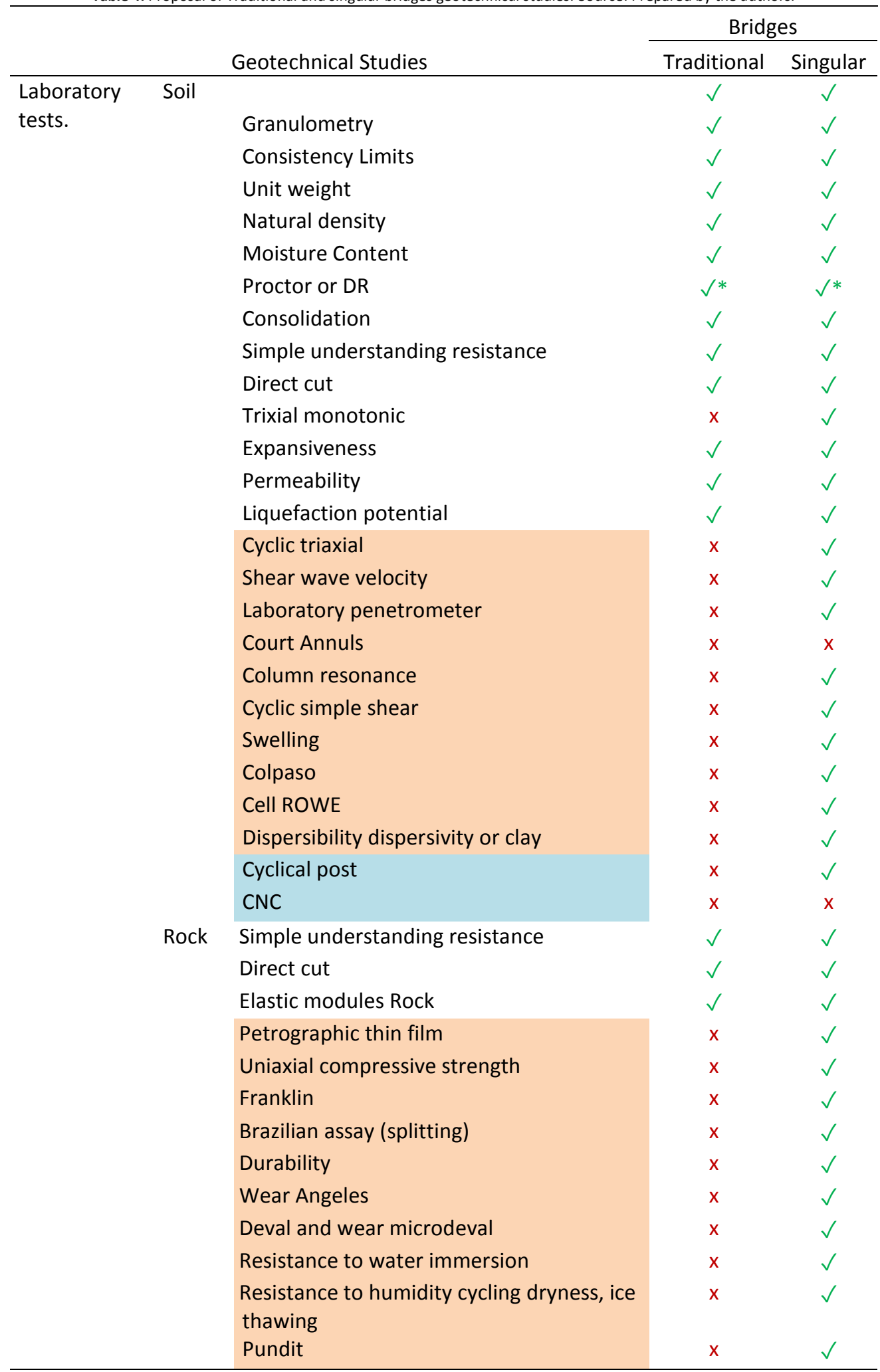

Table 5. Legend of Table 3 and Table 4. Source: Prepared by the authors.

\section{Considerations}

$\checkmark$ Test Always Performed

$x$ Test not performed

$\checkmark$ Dependig on soil type

Complementary tests regarding standards

Complementary test of Chacao Bridge 
Once the results are obtained and how it can be appreciated in Table 3 and 4, for singular projects there are several on site and laboratory tests that are not required for a traditional bridge.

Regarding the On Site tests, for singular projects all the soil and rock test are needed in contrast with very few test needed for traditional projects, even there are no rock test on site needed for traditional projects.

For laboratory tests, the results are similar, for singular projects there are several tests that are not necessary to perform for traditional bridges, this happens for soil, rock and even chemical tests.

Finally it is important to state that the summarized tests presented in Tables 3 and 4 are proposed and if the project presents particular conditions that require new tests this should be conducted, and here just a minimum tests are proposed.

\section{References}

AASHTO. (2012). AASHTO LRFD Section 10: Foundations. In AASHTO LRFD 2012 Bridge Design Specifications (6 th).

Arriagada, F., \& Contreras, M. (2015). Caracterización y requerimientos geotecnicos para el diseño de fundaciones de puentes tradicionales y singurales. Caso de estudio Puente Chacao. Pontificia Universidad Católica de Valparaíso, Undergraduate thesis.

Eurocode. (2011). Eurocode 7: Geotechnical Design. Available online at: https://www.thenbs.com/knowledge/eurocode-7-geotechnical-design

Ministerio de Fomento (2009). Guía de Cimentaciones en Obras de Carreteras. Madrid,España:Centro de publicaciones secretaría general técnica. ISSBN 10: 8449808626.

MOP. (2013). Bases Técnicas para la Licitación Pública de la Obra "Diseño y Construcción del Puente Chacao, Región De Los Lagos". Available online at: http://www.mop.cl/puentechiloe/Documents/Circular\%20Aclaratoria\%208\%20Construccion\%20Puente\%20Chacao.PDF

MOP. (2014). Manual de Carreteras. Available online at http://www.vialidad.cl/areasdevialidad/manualdecarreteras/Paginas/informativos.aspx

Peña, A., Marquez-Marambio, M., \& LLorens-Alcón, M. (2013). Analysis of the Influence of parasitic effects on piles in soft soils. Revista de La Construcción, 12 (1), 4-15.

Márquez, \& Valenzuela, M. (2014). Chacao Suspension Bridge: Special Structural Singularities, ACCT Chile - MOP. International Conference of Bridges. Future Challenges: Design, Constructions and Maintenance. Santiago, Chile.

Valenzuela, M., Marquez, M., \& Vallejo, I. (2015). Multi-span Bridges: The First Chilean Experience and Future Challenges. In Multi-span Bridges: The First Chilean Experience and Future Challenges. Porto, Portugal. 